This item was submitted to Loughborough's Research Repository by the author.

Items in Figshare are protected by copyright, with all rights reserved, unless otherwise indicated.

\title{
Application of lanthanide luminescence in probing enzyme activity
}

PLEASE CITE THE PUBLISHED VERSION

https://doi.org/10.1039/c8cc02824a

PUBLISHER

(C) Royal Society of Chemistry (RSC)

\section{VERSION}

AM (Accepted Manuscript)

\section{PUBLISHER STATEMENT}

This work is made available according to the conditions of the Creative Commons Attribution-NonCommercialNoDerivatives 4.0 International (CC BY-NC-ND 4.0) licence. Full details of this licence are available at: https://creativecommons.org/licenses/by-nc-nd/4.0/

\section{LICENCE}

CC BY-NC-ND 4.0

\section{REPOSITORY RECORD}

Hewitt, Sarah H., and Stephen J. Butler. 2019. "Application of Lanthanide Luminescence in Probing Enzyme Activity". figshare. https://hdl.handle.net/2134/35109. 


\section{Journal Name}

\section{COMMUNICATION}

\section{Application of lanthanide luminescence in probing enzyme activity}

Received 00th January 20xx, Accepted 00th January 20xx

\author{
Sarah H. Hewitt ${ }^{\mathrm{a}}$ and Stephen J. Butler*a
}

DOI: $10.1039 / \times 0 \times x 00000 x$

www.rsc.org/

Enzymes play critical roles in the regulation of cellular function and are implicated in numerous disease conditions. Reliable and practicable assays are required to study enzyme activity, to facilitate the discovery of inhibitors and activators of enzymes related to disease. In recent years, a variety of enzymes assays have been devised that utilise luminescent lanthanide(III) complexes, taking advantage of their high detection sensitivities, long luminescence lifetimes, and line-like emission spectra that permit ratiometric and time-resolved analyses. In this Feature Article, we focus on recent progress in the development of enzyme activity assays based on lanthanide(III) luminescence, covering a variety of strategies including $\operatorname{Ln}($ III)-labelled antibodies and proteins, $\operatorname{Ln}$ (III) ion encapsulation within defined peptide sequences, reactivity-based $\operatorname{Ln}$ (III) probes, and discrete $\operatorname{Ln}($ III) complexes. Emerging approaches for monitoring enzyme activity are discussed, including the use of anion responsive lanthanide(III) complexes, capable of molecular recognition and luminescence signalling of polyphosphate anions.

Assays to monitor enzyme reactions are vital for understanding enzyme mechanism and function and for the discovery of novel inhibitors. Therefore, the design of robust, sensitive and easy-to-use enzyme assays is of great importance for biological and pharmaceutical researchers. The search for new enzyme inhibitors typically begins with high-throughput screening of potential lead compounds, followed by measurements of selectivity and potency. ${ }^{1,2}$ To conduct these studies, assays are required that are amenable to highthroughput analyses, can be used in low volumes with low concentrations of expensive components, operate in aqueous buffer, and provide a readout with high signal-to-noise. ${ }^{3}$ The use of luminescence in enzyme assays is particularly attractive due to the high measurement sensitivity and rapid response times, permitting high-throughput analysis using standard well-plate techniques. ${ }^{4,5}$ In addition, the high sensitivity of luminescence $^{6}$ allows the use of low concentrations of

\footnotetext{
a. Department of Chemistry, Loughborough University, Epinal Way, Loughborough, LE11 3TU, UK. E-mail: s.j.butler@lboro.ac.uk; Tel: +44 (0)1509-222577
}

potentially costly assay components.

Most enzyme assays operate by monitoring the accumulation of product or the depletion of substrate. ${ }^{3}$ This can be achieved in a variety of ways, including the detection of a species labelled with a colourimetric or luminescent tag,7,8 or the detection of a native substrate or product using a luminescent reporter molecule, typically based on an antibody or a synthetic receptor. 4,9 Such assays can function in real-time, detecting the change in luminescence during the enzyme reaction, or can be single end-point, wherein the enzyme reaction is stopped prior to measurement. End-point assays can be valuable as the enzyme reaction can be performed in optimal conditions with native substrates; however, they require a separate enzyme reaction to be set up for each data point required and thus can be costly in terms of materials. ${ }^{10}$
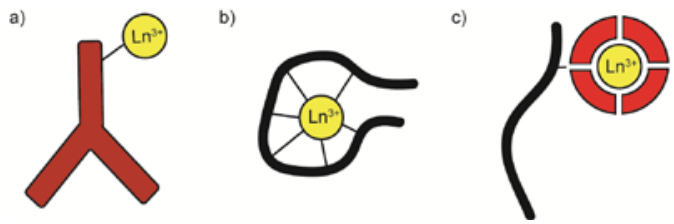

Figure 1. Strategies for monitoring enzyme reactions using lanthanide(III) complexes. a) $\operatorname{Ln}($ III) Labelled antibody, b) $\operatorname{Ln}($ III) ion encapsulation within a polypeptide sequence, c) Ln(III) labelled biomolecule, usually a peptide, d) Discrete lanthanide(III) complex.

In recent years, several new approaches to enzyme assays have been devised that exploit the attractive photophysical properties of luminescent lanthanide(III) complexes. ${ }^{11}$ Lanthanide-based enzyme assays may function in a number of ways. Firstly, reactivity-based probes have been developed, in which the Ln(III) complex or ligand is modified irreversibly during the enzyme reaction, ${ }^{12,13}$ altering its luminescence or chelating properties in the process. Secondly, $\operatorname{Ln}(\mathrm{III})$ ions have been incorporated directly into biological molecules, ${ }^{14-18}$ either by functionalising antibodies (Figure 1a), replacing endogenous $\mathrm{Ca}$ (II) ions in protein binding domains (Figure $1 \mathrm{~b}$ ), conjugating $\mathrm{Ln}$ (III) complexes to native amino acids or incorporating lanthanide-chelating, non-natural amino acids into peptides (Figure 1c). The luminescence properties of the 
incorporated $\operatorname{Ln}(\mathrm{III})$ ion are modulated during the enzyme reaction. Thirdly, discrete $\operatorname{Ln}($ III) complexes (Figure $1 \mathrm{~d}$ ) may be used that bind reversibly to a substrate or product of the enzyme reaction (e.g. peptides, anions, small molecules), ${ }^{19}$ reporting on the depletion or accumulation of these species by changes in emission intensity or lifetime of the Ln(III) complex. Herein, we discuss the applications of these different types of enzyme assay.

\section{Luminescent lanthanide(III) Complexes}

Luminescent lanthanide(III) complexes are generating increased interest in a range of bioanalytical studies, particularly those of europium(III) and terbium(III). ${ }^{20-22} \operatorname{Ln}(\mathrm{III})$ complexes offer several advantages over conventional organic fluorophores for use in biological applications, including a large separation between absorption and emission spectra, minimising excitation light interference, and line-like emission spectra with clearly defined bands, allowing ratiometric analyses. ${ }^{11,23}$ Emissive Ln(III) complexes are particularly attractive for their long luminescence lifetimes (Figure 2a), which permits the use of time-gated detection techniques to completely remove the autofluorescence from biological fluorophores (e.g. tryptophan (Trp) and tyrosine (Tyr) residues in proteins), thereby improving signal-to-noise ratio. ${ }^{24-27}$ Timegated luminescence can also be used with Förster resonance energy transfer (FRET) technology, ${ }^{28-30}$ allowing much longer emission lifetimes to be observed for a conventional organic fluorophore, following excitation from a lanthanide donor. This enables time-resolved FRET to be observed for an organic fluorophore, which exhibits very short-lived emission in the absence of the Ln(III) donor. Luminescent lanthanide(III) complexes have found increased practical use for a range of biological applications, ${ }^{11,21,31-33}$ including cellular imaging, sensing of biologically important analytes and diagnostics. a)

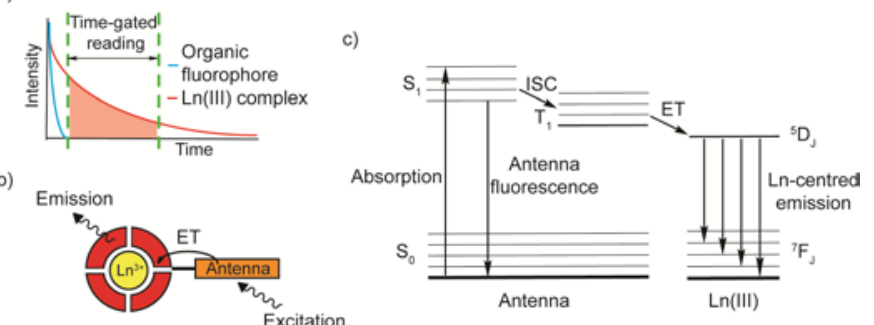

Figure 2. a) Long luminescence lifetime of the $\operatorname{Ln}($ III) complex, compared to conventional organic fluorophore, permitting time-gated luminescence measurements. b) Cartoon of antenna excitation. Excitation light excites the antenna, followed by energy transfer to the $\mathrm{Ln}($ III) ion, which consequently emits light. c) Simplified Jablonsk diagram depicting the antenna excitation for $\mathrm{Eu}(\mathrm{III})$ or $\mathrm{Tb}(\mathrm{III})$. The antenna is excited to its singlet state, energy is then transferred to its triplet state by intersystem crossin (ISC), followed by energy transfer to the lanthanide excited state, which consequently emit light on $r$ to the ground state.
Several aspects need to be considered in the design of a luminescent lanthanide complex. Firstly, the direct excitation of $\operatorname{Ln}(I I I)$ ions is very inefficient, due to the Laporte forbidden nature of the $f-f$ transitions. However, highly luminescent lanthanide complexes can be devised by incorporating a strongly absorbing chromophore (or antenna) into the ligand design. ${ }^{34}$ A simplified photophysical pathway for sensitisation of $\operatorname{Ln}$ (III) luminescence is shown in Figure $2 b$ and $c$, involving energy transfer from the triplet excited state of an absorbing antenna to the $\mathrm{Ln}(\mathrm{III})$ excited state, resulting in metal-centred luminescence. ${ }^{35}$ The participation of intra-ligand charge transfer states in the $\operatorname{Ln}($ III) sensitisation process has been associated with antennae containing donor and acceptor components separated by a conjugated system. ${ }^{36,37}$ The nature of the sensitising group can be particularly useful in designing responsive lanthanide probes, as changes to the antenna can modulate its absorption or energy transfer properties. These changes can result from irreversible reaction with biological analytes, ${ }^{12}$ or from reversible non-covalent interactions (e.g. $\pi$ $\pi$ stacking), ${ }^{38}$ perturbing the singlet or triplet excited states of the antenna.

Secondly, lanthanide ions typically adopt coordination numbers of between 8 and 10 in aqueous solution, ${ }^{39}$ so the ligand design must incorporate a sufficient number of hard donors to satisfy this coordination sphere. A wide range of kinetically stable 1:1 complexes of $\operatorname{Ln}(\mathrm{III})$ ions with heptadentate or octadentate ligands have been developed, ${ }^{40-}$ 44 often based on carboxylic acid functionalised cyclen, 9N3 macrocycles, or open DTPA or EDTA derivatives, but can also be well-defined peptide sequences. ${ }^{45}$ If the $\operatorname{Ln}($ III) coordination sphere is not satisfied, water molecules will occupy the remaining coordination sites, resulting in quenching of luminescence due to vibrational energy transfer to $\mathrm{O}-\mathrm{H}$ oscillators. ${ }^{46}$ The quenching effect of bound water molecules can be utilised in the design of responsive $\operatorname{Ln}($ III) complexes, ${ }^{20,47}$ wherein displacement of coordinated water by anionic species causes an enhancement in $\operatorname{Ln}(\mathrm{III})$ emission intensity and pronounced changes in emission spectral form, arising from a change in the primary coordination sphere of the $\operatorname{Ln}(\mathrm{III})$ ion. ${ }^{38,48} \mathrm{Eu}$ (III)-based probes that utilise this sensing mechanism can be ratiometric in nature, normally by observing the change in intensity of the hypersensitive electric-dipole transition $\left({ }^{5} D_{0}-{ }^{7} F_{2}\right)$, relative to the emission intensity of the magnetic-dipole transition $\left({ }^{5} D_{0}-{ }^{7} F_{1}\right)$, which is insensitive to changes in the coordination environment of the Ln(III) ion. ${ }^{49}$ Ratiometric analyses have also been achieved by using cocktails of lanthanide complexes, comparing bands from the two complexes to generate a ratiometric signal. Generally, this approach utilises a $\operatorname{Ln}($ III) complex that is sensitive to the presence of a particular species, and one which is invariant to changes in that species. ${ }^{50}$

\section{Reactivity based lanthanide probes}


Reaction of the sensitising antenna can modulate the luminescent properties of the lanthanide(III) complex, ${ }^{12}$ either by generating a chelating antenna from a non-chelating precursor or by changing the energy transfer properties of an already attached antenna. ${ }^{51}$ Many examples of the former approach were reported in the 1990s, the most common involving the generation of $\operatorname{Ln}(\mathrm{III})$ chelating salicylic acid derivatives via the hydrolysis of phosphoesters, ${ }^{13,52,53}$ oxidation of aldehydes ${ }^{13}$ or hydrolysis of glycosidic linkages, ${ }^{13,52}$ by alkaline phosphatase, xanthine oxidase and $\beta$ galactosidase respectively (Figure $3 a$ ). In each case, reversible binding of the salicylate derivative to Tb(EDTA) switches on $\mathrm{Tb}$ (III) luminescence. Other reactions monitored using the same approach have included horseradish peroxidase, ${ }^{54}$ esterases, ${ }^{55,56}$ lysozyme, ${ }^{57,58} \quad \beta$-glucosidase, ${ }^{59}$ lipase, ${ }^{59}$ and glucose oxidase. ${ }^{13}$ This methodology has been applied in an immunoassay technique called enzyme-amplified lanthanide luminescence (EALL), ${ }^{60}$ where an antigen is recognised by an antibody with an enzyme attached. This enzyme catalyses the formation of the chelating antenna from the non-chelating compound, which coordinates to the $\operatorname{Ln}(\mathrm{III})$ ion, providing a luminescent signal. The luminescence response is thus dependent on initial recognition of the antigen.

a)
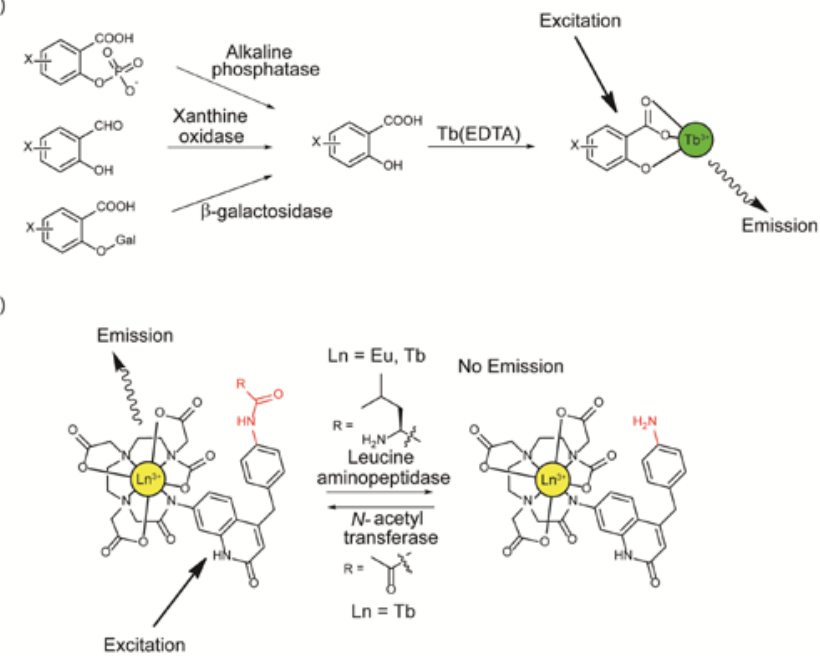

c)

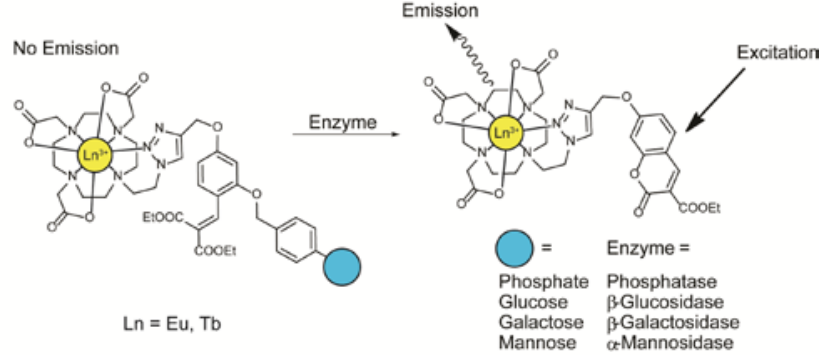

Figure 3. Reactivity based probes. a) Generation of a terbium(III) chelating salicylic acidbased antennae by various different enzyme reactions on appropriate substrates, leading to emissive $\mathrm{Tb}(\mathrm{III})$ complexes. b) Use of aniline quenching to monitor enzyme reactions ${ }^{61,62}$ c) Borbas' caged antenna, ${ }^{63,64}$ where an enzymatic reaction on an appropriate cage (blue circle) generates a coumarin antenna leading to lanthanide(III) emission.
Other reactivity-based probes function by chemical modification of a stable lanthanide complex with an integral sensitising group. The Nagano group prepared a $\mathrm{Tb}$ (III) complex, based on DTPA ligand bearing a salicylic acid derivative, for monitoring alkaline phosphatase (ALP) activity. Enzymatic hydrolysis of a phosphate monoester present on the salicylic acid hydroxyl group resulted in a bathochromic shift in the absorption spectrum of the chromophore, allowing ratiometric analysis of $\mathrm{Tb}(\mathrm{III})$ emission intensity upon excitation at two different wavelengths. 65 The same researchers utilised the singlet excited state quenching ability of an aniline moiety (by photoinduced electron transfer, PeT) on a quinolinone antenna, to detect the activity of a protease and $N$-acetyltransferase (Figure $3 b$ ), ${ }^{61,62}$ monitoring the hydrolysis or formation of an amide bond, respectively. When the aniline is present, the HOMO of this moiety transfers electrons to the singlet excited state of the antenna, deactivating it and preventing energy transfer to the lanthanide excited state. The corresponding amide has a lower energy HOMO, preventing PeT quenching of the antenna, promoting sensitisation of $\mathrm{Ln}(\mathrm{III})$ luminescence. Functionalisation of the aniline moiety with a leucine residue allowed continuous monitoring of the activity of a protease, microsomal leucine aminopeptidase (LAP), which hydrolyses most $\mathrm{N}$-terminal amino acids from peptides, with a preference for leucine or alanine. ${ }^{17}$ In subsequent work, $\mathrm{N}$ acetyltransferase (NAT) activity was monitored by observing the reverse PeT switching process: measuring the switching on of $\mathrm{Tb}$ (III) emission as the aniline is converted to an acetanilide group. This enzyme reaction could be monitored using both purified enzyme and in cell lysate. ${ }^{18}$

Kikuchi and coworkers originally developed a similar assay for protease activity, ${ }^{66}$ based on a stable $\mathrm{Tb}$ (III) complex bearing an aniline group that sensitises $\mathrm{Tb}(\mathrm{III})$ emission. The corresponding $\mathrm{Tb}$ (III) complex bearing an amide group was weakly luminescent, due to inefficient energy transfer to the $\mathrm{Tb}$ (III) emissive state. However, upon enzymatic hydrolysis the aniline is revealed, switching on luminescence. This aniline moiety was functionalised with two short peptides, allowing the activity of two different proteases, calpain I and leucine aminopeptidase, to be monitored according to the different peptide consensus sequences.

The Gunnlaugsson group have developed an assay using glycosylated $\mathrm{Tb}(\mathrm{III})$ cyclen complexes to follow glycosidase enzyme activity. ${ }^{67}$ Cleavage of the glycosidic bond in the presence an appropriate glycosidase, reveals a phenol antenna that increases the intensity of $\mathrm{Tb}$ (III) luminescence. This was used to detect the activity of $\beta$-glucosidase in real-time. However, the assay required high (millimolar) concentrations of the glycosylated $\mathrm{Tb}(\mathrm{III})$ probe, which gave rise to a gradual enhancement in luminescence in the absence of enzyme.

Enzyme activity may be monitored by ratiometric analysis of two emission bands of a single Ln(III) complex, or pairs of emission bands from two different $\operatorname{Ln}($ III) complexes of a common ligand. The Sames group utilised the latter approach to monitor esterase activity in real-time, using a 'cocktail' of 1:1 $\mathrm{Eu}(\mathrm{III}) / \mathrm{Tb}$ (III) complexes of a common DTPA ligand, bearing 
a single carbostyril antenna functionalised with an ethyl ester. Enzymatic hydrolysis of the ethyl ester lead to differential sensitisation of $\mathrm{Tb}$ (III) and $\mathrm{Eu}$ (III) luminescence. ${ }^{50}$ This enabled esterase hydrolysis activity to be monitored by measuring the intensity ratio of selected $\mathrm{Eu}(\mathrm{III}) / \mathrm{Tb}$ (III) emission bands.

The Borbas group have used a different approach, creating a Ln(III) complex with a 'caged' antenna precursor.63,64 The cage masks a phenolic $\mathrm{OH}$ group, which when revealed triggers an intramolecular cyclisation to generate a coumarin antenna, capable of sensitising $\mathrm{Eu}$ (III) or $\mathrm{Tb}$ (III) luminescence (Figure 3c). Variations in the nature of the cage moiety allowed the activity of different enzymes to be monitored, as well as the detection of various analytes (e.g. fluoride, $\mathrm{H}_{2} \mathrm{O}_{2}$ ). Functionalisation of a common ligand with cages bearing galactose, glucose, mannose and phosphate allowed $\beta$-galactosidase, $\beta$ glucosidase, $\alpha$-mannosidase and phosphatase activity to be monitored. Notably, the detection of $\beta$-galactosidase activity was reported in living lacZ bacteria. ${ }^{63}$

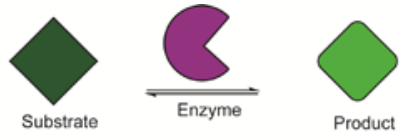
Incubate with
2*
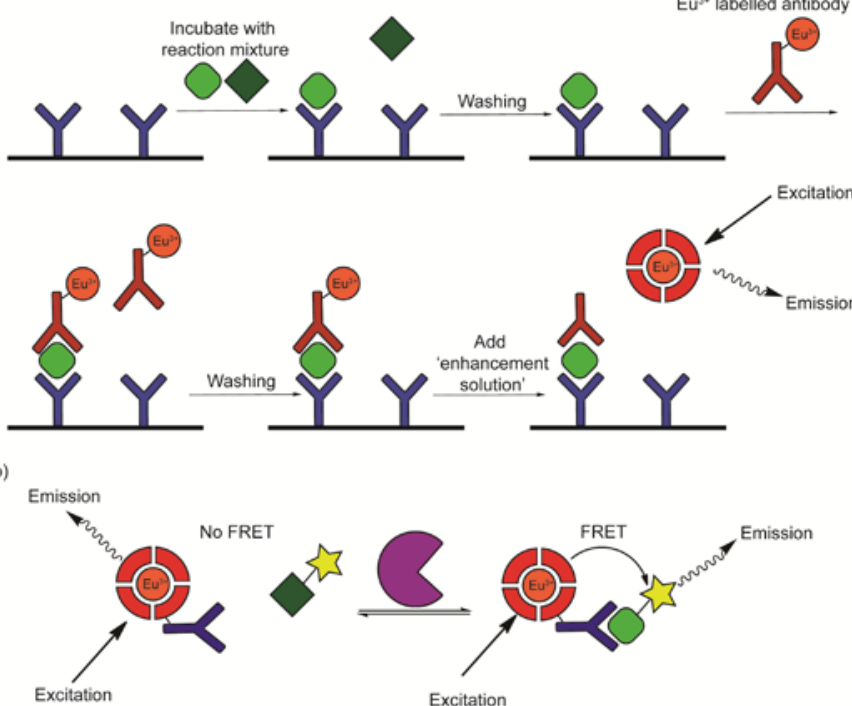

Figure 4. Lanthanide(III) labelled antibodies for monitoring enzyme reactions. a) Heterogeneous assay on a solid support. The enzymatic product is recognised by an antibody on a solid support, while the substrate is washed away. The antibody-antigen construct is recognised by a Eu(III) labelled antibody, and the excess washed away. Addition of an 'enhancement solution' dissociates the Eu(III) ion from the antibody, to give a luminescent complex which is detected. b) Homogeneous assay. A luminescent, $\mathrm{Eu}(\mathrm{III})$ labelled antibody recognises the fluorescently labelled enzymatic product, but not the substrate. This allows FRET to occur between the Eu(III) complex donor to the fluorescent label.

\section{Lanthanide labelled biomolecules}

\section{Labelled antibodies}

The use of lanthanide(III) labelled antibodies has been well developed, $27,52,60,68$ and utilised in several commercial enzyme assays. These assays can be divided into two classes: heterogeneous and homogeneous. Heterogeneous assays (Figure 4a) rely on the recognition of the enzyme reaction mixture by an antibody bound to a solid support, as exemplified by Perkin Elmer's DELFIA ${ }^{\circledR}$ (dissociation enhanced lanthanide fluorescence immunoassay). ${ }^{27,60,69-71}$ The antibodyantigen construct is then recognised by a $\operatorname{Ln}$ (III) labelled antibody. Addition of an enhancement solution dissociates the lanthanide(III) ion from the antibody and generates a luminescent $\operatorname{Ln}($ III) species, usually by providing a coordinating $\beta$-diketonate antenna. This assay methodology allows detection of low concentrations of enzyme reaction substrate/product (less than $10^{-17} \mathrm{~mol} /$ well) with high signal to noise, but is not particularly high-throughput, as it requires multiple washing steps. The homogeneous assays (Figure $4 \mathrm{~b}$ ) operate on a similar principle, ${ }^{26,72-74}$ however the detection strategy is different. Generally, the enzyme substrate and product are labelled with an organic fluorophore, either by recognition by a labelled antibody (cisbio's $\mathrm{HTRF}^{\circledR}$ ) or by direct labelling of the substrate peptide (Perkin Elmer's Lance ${ }^{\circledR}$ or ThermoFisher Scientific's Lanthascreen ${ }^{\mathrm{TM}}$ ). The enzymatic product is then recognised by a $\operatorname{Ln}($ III)-labelled antibody, which acts as a FRET donor to the organic fluorophore, allowing timeresolved FRET to be observed. Other homogenous assays rely on the competition for binding between the enzymatic product or substrate and a fluorescently labelled analogue, exemplified by Thermofisher Scientific's Adapta ${ }^{\circledR}$ and another version of cisbio's HTRF $^{\circledR}$ assays. These homogeneous assays are much more high-throughput relative to the heterogeneous assays, and provide high sensitivity; however, they are still end-point assays, which precludes their use for monitoring enzymatic reactions in real time.

Adaptations to these antibody-based assays have been made to obviate the need for the labelled antibody. To this end, an assay for Cds1/Chk2 kinase activity was developed, ${ }^{75}$ following the same groups use of a more conventional HTRF assay. ${ }^{76}$ This assay relies on the chemical conversion of the enzymatically generated phosphoserine residue on a biotinylated peptide to a Cyanin 5 luminescence acceptor, followed by addition of an $\mathrm{Eu}(\mathrm{III})$-cryptate functionalised streptavidin bead to capture the peptide. The ratio of Eu(III) emission to Cy5 emission can be used to signal the progress of the enzyme reaction.

\section{Terbium(III) ion binding to peptide and proteins}

The incorporation of lanthanide(III) ions into peptides and proteins is an active field of research, facilitating spectroscopic characterisation of protein structure using photophysical, NMR and X-ray crystallographic techniques. ${ }^{15,77-80}$ The first reports of incorporation of lanthanide(III) ions into proteins were based on endogenous calcium(II) binding sites, replacing $\mathrm{Ca}$ (II) ions with $\mathrm{Tb}(\mathrm{III})$ ions, which have a similar ionic radius and oxophilicity. ${ }^{81-83} \mathrm{~Tb}(\mathrm{III})$ ions are advantageous in this regard as tryptophan residues within the protein can act as suitable antennae to generate emissive species. This methodology was used to perform some basic enzyme studies, including the study of metal ion binding to trypsin, ${ }^{83} \alpha$-chymotrypsin, ${ }^{83}$ and heparinase, 84 and inhibitor binding to elastase. ${ }^{82}$ More 
recently, Hamachi and coworkers have used a known $\mathrm{Tb}$ (III) binding site along with fluorescein-labelling in the mannose binding protein, Concanavalin A, to develop a FRET assay for tracking the enzymatic hydrolysis of mannose from a glycoprotein by $\alpha$-mannosidase. ${ }^{85}$

The Imperiali group have worked extensively on the development of lanthanide binding tags (LBTs), 15,45,86-92 comprising between 17 and 23 amino acids which can coordinate to lanthanide(III) ions, predominantly via aspartate and glutamate residues. Typically, the peptide contains a tryptophan residue to sensitise a coordinated $\mathrm{Tb}$ (III) ion. LBTs can be incorporated into proteins using standard recombinant protein techniques, or synthesised as peptides and tagged to the protein of interest via cysteine (Cys) residues. Initially these LBTs were based on a calcium(II) binding loop of the EFhand, but split-and-pool peptide synthesis techniques lead to the development of novel peptides with high affinities for terbium(III), ${ }^{87,93}$ with $K_{\mathrm{D}}$ values measured between $9 \mu \mathrm{M}$ and $220 \mathrm{nM}$ in buffered aqueous solution. Further developments involved the use of non-natural amino acids bearing acridone or carbostyril chromophores, allowing sensitisation of a coordinated $\mathrm{Eu}$ (III) ion. ${ }^{86}$ LBTs have been attached to several different proteins including ubiquitin ${ }^{88}$ and interleukin- $1 \beta, 45$ enabling optical visualisation of proteins both in vitro and in cellulo, as well as aiding in NMR and X-ray crystallographic studies. Using a similar approach to LBTs, a variation on a zinc finger was developed, termed a 'lanthanide finger', which incorporates a $\beta \beta \alpha$ tertiary structure, using four carboxylate $\left(\mathrm{Asp}_{2} \mathrm{Glu}_{2}\right)$ residues to bind a $\mathrm{Tb}(\mathrm{III})$ ion, and a tryptophan residue for sensitisation of luminescence. ${ }^{94}$ Stabilisation of the peptide secondary structure was found to increase $\operatorname{Ln}(\mathrm{III})$ binding affinity.

Lanthanide binding tags have been utilised to monitor protease activity. ${ }^{92} \mathrm{~A}$ genetically encoded protein consisting of a green fluorescent protein (GFP) and an LBT, separated by a linker containing cleavage sites for the proteases caspase and trypsin (Figure 5a). When the protein construct is intact, longlived FRET occurs between the $\mathrm{Tb}$ (III) donor (present in the LBT) and the proximate GFP acceptor. Upon proteolytic cleavage of the linker, the LBT and GFP components are no longer in close proximity and FRET does not occur, hence the long-lived fluorescence of GFP is not detected. The utility of this assay was demonstrated by obtaining caspase- 3 enzyme dose response curves and inhibitor dose response curves.

\section{Using phosphorylation to affect $\operatorname{Ln}(\mathrm{III})$ ion peptide binding}

The reversible phosphorylation of serine (Ser), threonine (Thr) and tyrosine (Tyr) residues on proteins regulates a wide range of signal transduction events, directing cellular processes including proliferation, trafficking and adhesion.95,96 Misregulation of the phosphorylation and dephosphorylaiton process, catalysed by kinases and phosphatases respectively, has been implicated in various diseases including cancer. Therefore, the need for simple, precise methods to monitor reversible phosphorylation of peptides and proteins is well recognised in drug discovery.
The phosphorylation state of a peptide or protein can have a profound effect on its ability to coordinate lanthanide ions. This was first shown using a peptide fragment of $\alpha$ synuclein, ${ }^{97,98}$ containing two phosphorylation sites (Tyr125 and Ser129) with flanking Glu and Asp residues. Phosphorylation of either the tyrosine or serine residue increased the $\mathrm{Tb}$ (III) binding affinity; a $K_{\mathrm{D}}$ value of $300 \mathrm{nM}$ was measured for the $1: 1$ complex of the peptide bearing phosphorylated Tyr125 residue.

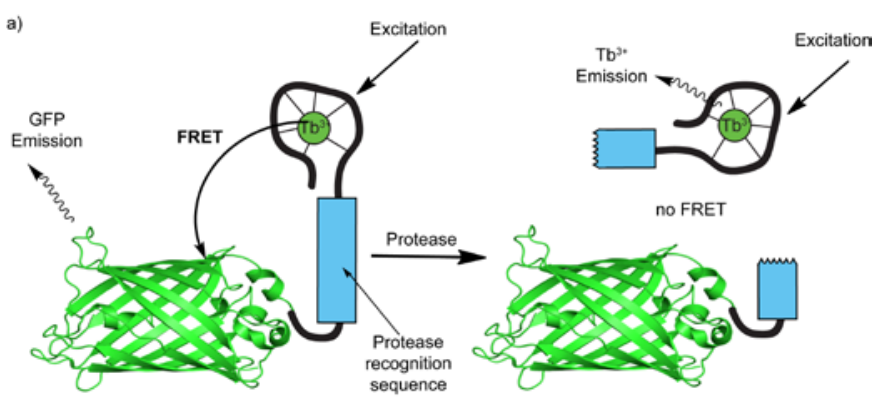

b)

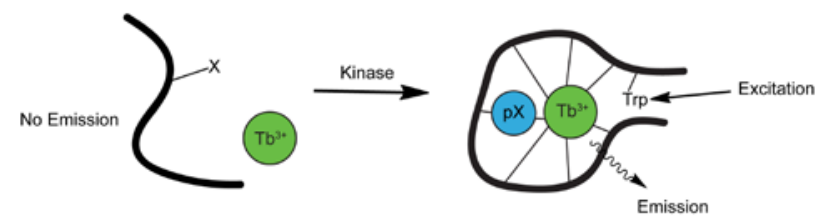

Figure 5. Use of lanthanide binding tags (LBTS) for monitoring enzyme reactions. a) Detection of protease activity by FRET from the LBT to GFP. Upon proteolytic cleavage at the protease recognition sequence, the LBT and GFP are no longer part of the same construct so FRET does not occur, and $\mathrm{Tb}(\mathrm{III})$ emission is observed ${ }^{92}$. b) Protein kinase inducible domain, 99 phosphorylation of an amino acid (X) generates a $\mathrm{Tb}(\mathrm{III})$ ion chelating peptide, creating a luminescent complex. In this case a tryptophan residue, or phosphotyrosine residue, acts as the lanthanide antenna.

The Zondlo group used a variation of the lanthanide binding tags to monitor kinase activity, ${ }^{99}$ wherein the phosphorylation of a serine residue modulates the binding affinity of a $\mathrm{Tb}$ (III) ion (Figure 5b). It was found that a Glu residue, important for structure and $\mathrm{Tb}$ (III) ion binding within the LBT, could be replaced with a phosphoserine residue to create an emissive 1:1 complex with $\mathrm{Tb}(\mathrm{III})$, whereas the peptide bearing a nonphosphorylated serine was unable to bind a $\mathrm{Tb}$ (III) ion, hence no $\mathrm{Tb}$ (III) centred emission was observed. Upon phosphorylation of the peptide, coordination of the $\mathrm{Tb}$ (III) ion, in close proximity to a Trp antenna, resulted in sensitised $\mathrm{Tb}$ (III) luminescence. This was termed a 'protein kinaseinducible domain' (pKID). Such domains were designed to contain minimal consensus sequences for different kinases, including protein kinase A (PKA), protein kinase $C$ (PKC) and mitogen-activated protein kinase (MAPK). The end-point phosphorylation was detected for PKA. In subsequent work, this approach was developed for use with Tyr/pTyr residues, allowing the action of $\mathrm{Abl}$ kinase and YOP (a tyrosine phosphatase) to be detected. ${ }^{100}$ 
Other phosphotyrosine (pTyr) containing peptides have been developed that bind to $\mathrm{Tb}(\mathrm{III})$, using the pTyr residue to sensitise $\mathrm{Tb}$ (III) emission. ${ }^{101-105}$ An acidic peptide was used, containing a central tyrosine residue, which acts as a specific substrate for spleen tyrosine kinase (Syk). ${ }^{101,106}$ The phosphorylated peptide was found to bind $\mathrm{Tb}$ (III) ions 5 times more strongly than to the non-phosphorylated analogue, and with a substantial increase in emission intensity. This difference was used to monitor phosphorylation by Syk, and to determine the $\mathrm{IC}_{50}$ of the known Syk inhibitor, piceatannol. Using the same strategy, a peptide substrate for anaplastic lymphoma kinase (ALK) was prepared, whose phosphorylation could be monitored by measuring the increase in emission intensity upon $\mathrm{Tb}(\mathrm{III})$ ion binding. ${ }^{103}$ This assay was developed further to monitor two enzyme reactions simultaneously, using FRET based techniques. ${ }^{102}$ Labelling of the Syk peptide substrate with 5-carboxyfluorescein, and a phosphorylationdependent $\mathrm{Tb}$ (III) binding substrate of Lyn with cyanine 5 , the emission of the two fluorophores could be detected separately. Using time-resolved FRET from the $\mathrm{Tb}(\mathrm{III})$ ion donor, the fluorescence emission of both organic fluorophores was dependent on phosphorylation and was therefore used to monitor the activity of the two enzymes independently, in the same assay. Tagging the phosphorylation-dependent $\mathrm{Tb}$ (III) ion binding peptides with biotin, ${ }^{104}$ allowed its strong interaction with streptavidin functionalised quantum dots, which were also used for time-resolved FRET signalling of the activity of Src and Syk kinases.

However, as is the case for all of these assays, the presence of free $\mathrm{Tb}$ (III) ions can be a considerable drawback, because these ions can interact with nucleotides or nucleic acids present in the sample, resulting in unwanted background emission . ${ }^{107,108}$

\section{Attaching lanthanide complexes to peptides and proteins}

Other methods for labelling proteins and peptides with lanthanide(III) ions involve covalent attachment of a stable lanthanide(III) complex to amino acid residues within proteins, ${ }^{109-112}$ or to incorporate non-natural, chelating amino acids into peptides, often based on aminodiacetate ligands. ${ }^{14}$ Similar strategies using conventional fluorophores are common practice in the design of many biological assays for ligand binding and enzyme activity. ${ }^{113-115}$ Lanthanide-based peptide probes have been used most extensively for monitoring kinase and phosphatase reactions. ${ }^{17}$ The use of peptide-based biosensors for phosphorylation can be advantageous, as the sensing of phosphorylation state can, in certain cases, occur in the presence of other phosphate species, such as ATP and ADP. ${ }^{17}$

Initial studies using a simple lanthanide ligand attached to a serinetryptophan or phosphoserine-tryptophan dipeptide, ${ }^{116}$ using the tryptophan as an antenna, found that terbium(III) emission was increased with the non-phosphorylated ligand, compared to the phosphorylated ligand. This was attributed to a switch between a monomer and dimer with the phosphorylated and nonphosphorylated peptide, respectively. This change in emission was used to follow the enzymatic dephosphorylation of the phosphorylated peptide, using alkaline phosphatase. Further development involved modification of the chelating ligand, introducing a non-natural quinolone antenna and a bulky isoleucine residue between the antenna and the phosphorylated amino acid (now tyrosine), and extending the $\mathrm{N}$-terminus of the peptide. This allowed a $\mathrm{Tb}$ (III) and $\mathrm{Eu}$ (III) labelled peptide to be created, which displayed increased luminescence emission on phosphorylation (Figure 6a). ${ }^{117}$ This was used to monitor the conversion between the phosphorylated and non-phosphorylated peptides using the tyrosine phosphatase PTP1B or the tyrosine kinases ab1 and Src.

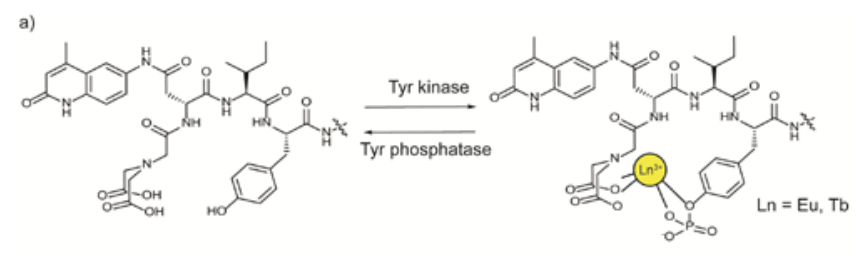

b)
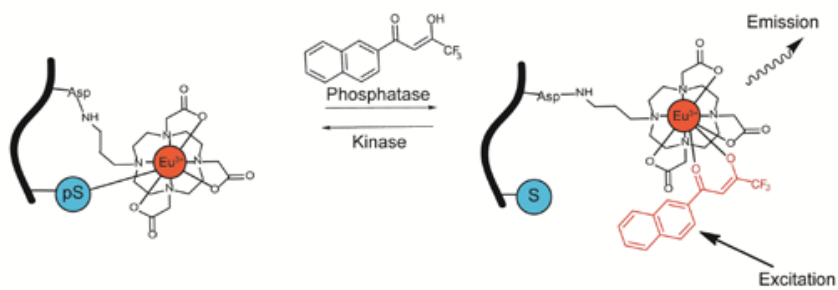

c)

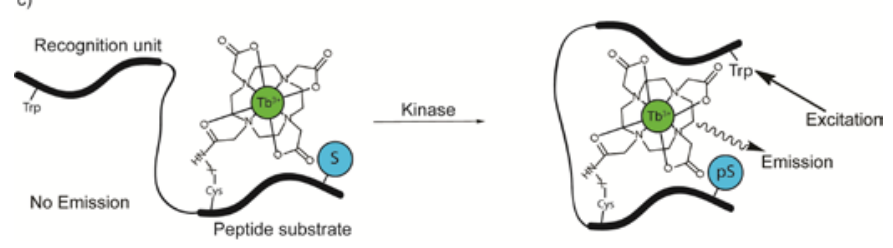

Figure 6. Use of lanthanide(III) complexes attached to peptides to monitor enzyme reactions. a) Monitoring tyrosine kinase and phosphatase activity on a short pentapeptide. Upon phosphorylation of a tyrosine residue, the peptide becomes a lanthanide chelator, generating a luminescent species. ${ }^{117}$ b) An Eu(III) complex attached to an aspartic acid residue in a peptide coordinates to a phosphoserine residue. On dephosphorylation by a phosphatase, the Eu(III) complex coordinates to a $\beta$-diketonate antenna to generate an emissive Eu(III) complex. Phosphorylation of the serine residue by a kinase displaces the $\beta$-diketonate antenna, switching off $\mathrm{Eu}(\mathrm{III})$ luminescence. ${ }^{118} \mathrm{c}$ ) Peptide labelled on a cysteine residue with a $\mathrm{Tb}$ (III) complex used to follow a kinase reaction. Phosphorylation of a serine residue on the peptide substrate results in interaction of the peptide with the recognition unit, bringing a tryptophan antenna in close proximity to the $\mathrm{Tb}(\mathrm{III})$ complex, generating an emissive species. ${ }^{119}$

More recently, lanthanide(III) complexes with high kinetic and thermodynamic stability have been conjugated to peptides to monitor kinase and phosphatase activity. The luminescence of the attached complex is affected by the phosphorylation state of a proximate serine or tyrosine residue within the peptide. ${ }^{118}$ A lanthanide complex $(\mathrm{Ln}=\mathrm{Eu}, \mathrm{Tb})$, based on a DO3A propylamino ligand, was attached to an Asp residue of a resinbound peptide using orthogonal protecting group chemistry. Coordination of a proximate phosphoserine residue caused competitive displacement of a $\beta$-diketonate antenna from the $\mathrm{Eu}$ (III) complex, resulting in a decrease in $\mathrm{Eu}(\mathrm{III})$ intensity (Figure 6b). Such 'switching off' of luminescence was used to monitor the PKC $\alpha$-catalysed phosphorylation of the peptide, determining Michaelis-Menten parameters for the enzyme. 
Conversely, the alkaline phosphatase catalysed dephosphorylation reaction could be monitored by observing an increase in $\mathrm{Eu}(\mathrm{III})$ emission intensity upon preferential binding to the $\beta$-diketonate antenna. More recently, an assay for CDK4/cyclin D kinase activity was developed (Figure 6c), ${ }^{119}$ capable of operating in melanoma cell extracts and reporting on CDK4 inhibition. The $\mathrm{Tb}$ (III)-based biosensor comprises a CDK4 substrate sequence attached to a recognition domain for the phosphorylated peptide. The DO3A Tb(III) complex was conjugated to the peptide substrate via a cysteine residue using maleimide chemistry, while a tryptophan antenna was positioned in the recognition domain. In the unphosphorylated state, the recognition peptide is distant from the substrate peptide, so inefficient sensitisation of $\mathrm{Tb}$ (III) emission occurs. However, upon phosphorylation, the recognition domain binds to the substrate peptide, increasing proximity of the tryptophan residue and the efficiency of $\mathrm{Tb}(\mathrm{III})$ sensitised emission.

The Komiyama group prepared a binuclear $\mathrm{Tb}(\mathrm{III})$ complex, based on two DOTAM (tetramide) ligands with an alkyne functionalised ethylene linker, for conjugation to an optimised substrate for protein tyrosine kinase Abl, via click chemistry. ${ }^{120}$ Intramolecular coordination of a phosphotyrosine residue to the bis- $\mathrm{Tb}$ (III) complex enabled energy transfer from the excited pTyr group to the $\mathrm{Tb}(\mathrm{III})$ centre. This biosensor and its derivatives, based on other peptide sequences, were used to monitor the activity of $\mathrm{Abl}$ and $\mathrm{Src}$, deriving Michaelis-Menten parameters and calculating $\mathrm{IC}_{50}$ values for known inhibitors (e.g. dasatanib).

Recently, the Härmä group have developed a quenching resonance energy transfer (QRET) assay for monitoring the activity of different enzymes, including kinases, phosphatases and deacetylases. ${ }^{121}$ The assay is based on disruption of a leucine zipper peptide pair interaction. An Eu(III)-chelate was attached to the $N$-terminus of a 'detection peptide', which forms a stable dimer with an enzyme substrate peptide. The peptide pair is luminescent, as the Eu(III) chelate is protected from quencher molecules present in solution. Enzymatic modification of the peptide substrate (e.g. phosphorylation) causes dissociation of the peptide pair and exposure to quencher molecules, decreasing the Eu(III) emission intensity. The peptide pair re-associates when the phosphate group is cleaved from the substrate, allowing both kinase and phosphatase activity to be monitored, demonstrated using PKA and PTP1B, respectively. This approach eliminates the need to chemically modify the substrate peptide, providing a potentially versatile platform for monitoring different enzyme catalysed post-translational modifications.

\section{Lanthanide-labelled small molecules and anions}

Various small molecules involved in enzyme reactions may also be labelled with lanthanide(III) complexes. The Härmä group have used terbium(III) labelled phosphoanions (e.g. GTP) $122-128$ in QRET assays for various applications, including ligandreceptor binding and monitoring GTPase reactions. The QRET assay relies upon binding of the labelled small molecule or anion to its receptor, masking the $\operatorname{Ln}(\mathrm{III})$ ion from quenching molecules in solution, switching on its luminescence (Figure 7a). Dissociation of the labelled species from its receptor causes quenching of Ln(III) emission intensity.

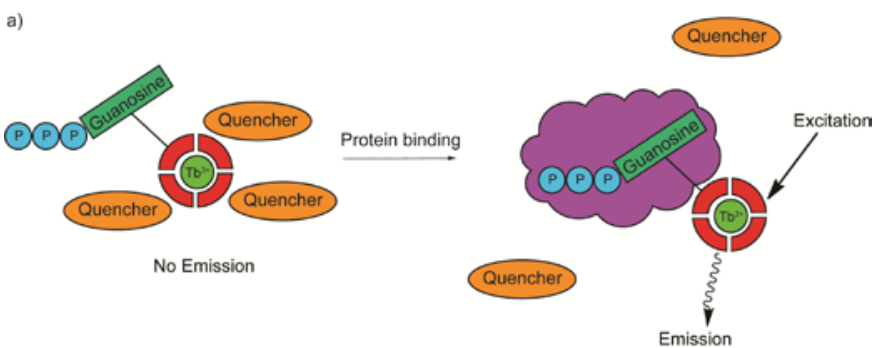

b)

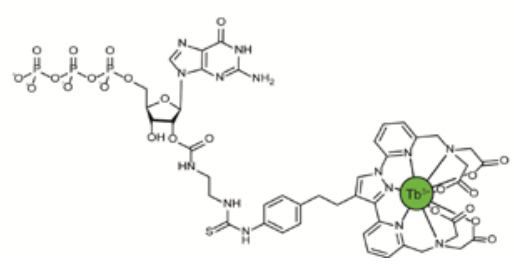

Figure 7. Using labelled GTP to monitor enzyme reactions. a) QRET strategy for monitoring GTP binding to a GTPase. When unbound to a protein the $\mathrm{Tb}(\mathrm{III})$ labelled GTP is surrounded by quencher molecules which quench the $\mathrm{Tb}(\mathrm{III})$ luminescence. On binding of the $\mathrm{Tb}$ (III) labelled GTP to a protein (promoted by a GEF), the $\mathrm{Tb}$ (III) is masked from the quencher molecules in solution and becomes emissive. ${ }^{128} \mathrm{~b}$ ) Structure of $\mathrm{Tb}$ (III) labelled GTP. ${ }^{129}$

Vuojola and coworkers first synthesised a Tb(III) and Eu(III) labelled GTP (Tb(III)-GTP shown in Figure 7b), attached to the ribose moiety via a thiourea linkage, to study GTPase activity using a guanine nucleotide exchange assay. ${ }^{129}$ GTPases behave as molecular switches, cycling between a GDP bound (inactive) and GTP bound (active) conformation in a controlled manner. GTP/GDP exchange is promoted by guanine nucleotide exchange factors (GEF), whereas the GTPase activity is promoted by a GTPase-activating proteins (GAP). Binding of GTP to the GTPase Rab21 was monitored using the $\operatorname{Ln}($ III)labelled GTP, by following exchange of the guanine nucleotide on a GFP or YFP labelled Rab21, using FRET. When guanine nucleotide exchange was occurring, the Ln(III)-GTP (FRET donor) competes with GTP for interaction with Rab21. Excitation of the bound Ln(III)-donor allows energy transfer to the proximal GFP or YFP acceptor. When nucleotide exchange was not occurring, no FRET induced GFP or YFP emission was observed.

The same Tb(III)-labelled GTP was utilised by the Härmä group to monitor guanine nucleotide exchange of the small GTPase Ras, using a QRET strategy. ${ }^{123}$ This approach obviates the need for a GFP or YFP fused protein, but additionally requires the use of quencher molecules. In subsequent work, a heterogeneous assay to study GTP hydrolysis (Ras deactivation) was developed. ${ }^{130}$ The assay utilised an antibody selective for GTP (over GDP, ATP and CTP) to determine the endogenous GTP concentration. An Eu(III) chelate was conjugated to streptavidin, which was bound strongly to biotin-labelled GTP. This streptavidin-bound GTP competes with endogenous GTP for interaction with the surface-bound antibody. After washing, the binding of the Eu(III)-labelled biotin-streptavidin species was reported by time-resolved 
luminescence emission, providing an indirect measure of endogenous GTP and hence the extent of GTP hydrolysis. Using this approach, initial studies of inhibitors of the proteinprotein interactions necessary for Ras functioning were conducted. Recently, this assay was further developed for use in a homogeneous assay, ${ }^{131}$ using a QRET strategy to provide a HTS-compatible platform for GTPase inhibitor/activator screening.

\section{Using discrete responsive lanthanide probes}

Discrete Ln(III) complexes may be used to follow an enzyme reaction, by binding reversibly to a substrate or product, reporting on the depletion or accumulation of these species by a change in luminescence emission or lifetime of the $\operatorname{Ln}($ III) complex. The use of discrete lanthanide complexes in enzyme assays offer advantages over the labelling of peptides or small molecules. Firstly, they enable the use of native enzymes and substrates, ensuring that enzyme reaction rates and inhibition are not affected by the presence of a bulky label on the enzyme or substrate. Secondly, the selective recognition of generic small molecules (e.g. nucleoside anions) or motifs in peptides could allow general assays to be developed that are broadly applicable for studying a range of different enzymes using a single probe, as opposed to the need to create a new labelled biomolecule for each individual enzyme reaction. Thirdly, Ln(III) complexes with high kinetic and thermodynamic stability can be designed for use in robust assays, minimising potential errors in measurements that may arise due to slow dissociation of the $\operatorname{Ln}(\mathrm{III})$ ion in solution.

\section{Phosphopeptide recognition using lanthanide complexes}

Discrete lanthanide complexes have been used to detect posttranslational modifications of peptides. For example, the Parker group have developed cationic Eu(III) complexes for the recognition of phosphorylated amino acid residues, ${ }^{132-135}$ both as free amino acids and in short peptide sequences. Reversible binding of phosphorylated Tyr, Ser and Thr residues to the Eu(III) metal, lead to modulation of europium(III) emission intensity and spectral form, as well as changes in NMR spectra. The preferential binding to pTyr over pSer ( $\log K_{\mathrm{a}}$ values of 4.2 and 2.7, respectively, in 0.1 M MOPS at pH 7.4) was utilised to detect various phosphorylated insulin receptor peptides, possessing differing numbers of pTyr residues. ${ }^{133}$

The Komiyama group designed a binuclear $\mathrm{Tb}$ (III) complex which acts as a probe for tyrosine phosphorylation (Figure $8),{ }^{136}$ following the initial use of a mononuclear Tb(III) DOTAM complex for sensing phosphotyrosine, both as a free amino acid and within a nonapeptide. ${ }^{137}$ The cationic bis-Tb(III) complex binds to a range of phosphate species via electrostatic interactions, including phosphorylated
Ser/Thr/Tyr residues and nucleoside mono- and triphosphate anions. However, the probe provides a distinctive 'switching on' of emission intensity upon binding to pTyr, due to energy transfer from the excited phenolic chromophore to the proximate $\mathrm{Tb}(\mathrm{III})$ centre. This increase in emission intensity was used to continuously monitor the Src kinase catalysed phosphorylation of a highly negatively charged peptide substrate. Using the same anionic substrate, this $\mathrm{Tb}(\mathrm{III})$ complex was later utilised to monitor different kinases (Fyn and EGFR), two protein tyrosine phosphatases and to obtain dose response curves for known inhibitors of these enymes. ${ }^{138}$ It should be noted that in this strategy, the detection sensitivity of the probe diminishes notably when the substrate peptides contain positively charged amino residues, which repel the $\mathrm{Tb}$ (III) complex, suppressing the modest Coulombic attraction between the probe and pTyr. Subsequent efforts to address this issue involved conjugation of the binuclear $\mathrm{Tb}$ (III) complex to peptide substrates, allowing intramolecular association of the pTyr residue, as described previously. ${ }^{120}$
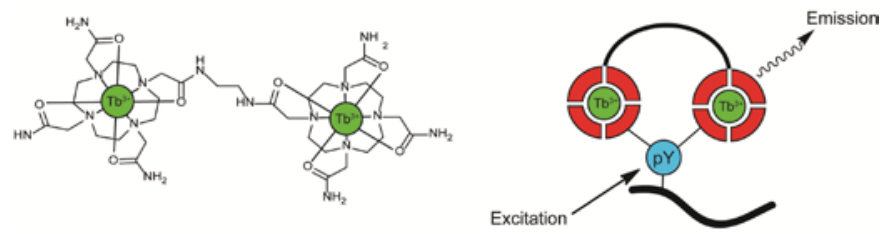

Figure 8. A binuclear $\mathrm{Tb}$ (III) complex (left), which is able to bind to a phosphotyrosine residue on a peptide, which acts as an antenna for $\mathrm{Tb}(\mathrm{III})$ sensitisation. ${ }^{136}$

\section{Anion and small molecule binding to lanthanide probes}

Significant progress has been made over the last 15 years, in the development of lanthanide complexes capable of binding and sensing a variety of anions, and small molecules. ${ }^{36,38,48,139-}$ 143 Here, we focus on their application in monitoring enzyme reactions.

A luminescence quenching assay has been developed to monitor the enzymatic conversion between the coenzymes $\mathrm{NAD}(\mathrm{P}) \mathrm{H}$ and $\mathrm{NAD}(\mathrm{P})^{+} .{ }^{144,145} \mathrm{~A}$ short series of stable $\mathrm{Tb}(\mathrm{III})$ complexes containing an azaxanthone chromophore were prepared (including Figure 9a), based on previous design by Parker, ${ }^{146}$ which was shown to be susceptible to dynamic quenching by various endogenous anionic reductants (e.g. ascorbate, urate). Similarly, $\mathrm{NAD}(\mathrm{P}) \mathrm{H}$ was found to interact with the positively charged $\mathrm{Tb}(\mathrm{III})$ complexes, dynamically quenching their luminescence, whereas $N A D(P)^{+}$did not bind to an appreciable extent so had little effect on the $\mathrm{Tb}$ (III) emission intensity. The quenching response observed in the presence of NADH was used to monitor the activity of lactate dehydrogenase, which catalyzes the reduction of pyruvate to Llactate, converting $\mathrm{NADH}$ into $\mathrm{NAD}^{+}$in the process. 
The Gunnlaugsson group have developed a $\mathrm{pH}$-responsive $\mathrm{Eu}(\mathrm{III})$ probe for monitoring urease activity (Figure $9 \mathrm{~b}$ ). ${ }^{147}$ The luminescence of the Eu(III) complex is changed from being highly emissive to weakly emissive on conversion of urea to ammonia and carbon dioxide, due to the change in $\mathrm{pH}$ of the solution (from pH 6 to $\mathrm{pH}$ 8). This 'switching-off' of luminescence enabled profiling of urease activity, and the determination of rate constants and activation energies for the enzyme. Impressively, the probe was further developed for use in a stable hydrogel matrix, demonstrating the potential for incorporation into catheters, for the detection of urinary tract infections in the clinic.
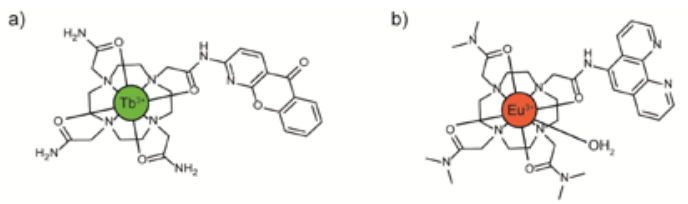

c)
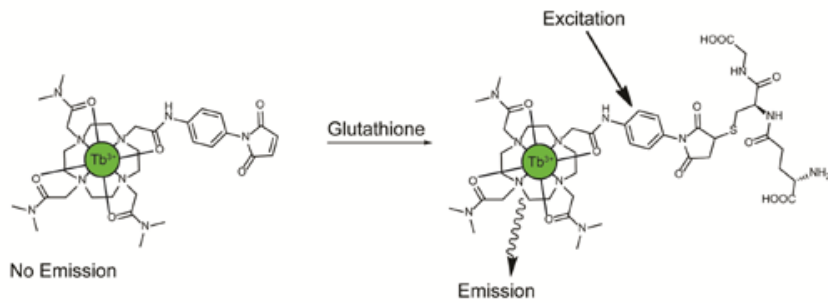

Figure 9. Lanthanide(III) complexes capable of binding to small molecules. a) $\mathrm{Tb}$ (III) complex that binds non-covalently to $\mathrm{NAD}(\mathrm{P}) \mathrm{H}$ over $\mathrm{NAD}(\mathrm{P})^{+}$, enabling the activity of lactate dehydrogenase to be monitored. ${ }^{144}$ b) $\mathrm{pH}$ responsive $\mathrm{Eu}(\mathrm{III})$ probe used to monitor urease activity. ${ }^{147} \mathrm{c}$ ) $\mathrm{Tb}(\mathrm{III})$ probe for sensing of glutathione. Glutathione reacts with the maleimide moiety to generate an emissive species. This was used to monitor the activity of glutathione reductase. ${ }^{148}$

Gunnlaugsson also reported a terbium(III) complex, based on a DOTAM derivative functionalised with a maleimide arm, for the sensing of thiols (Figure 9c), ${ }^{148}$ such as glutathione, a key cellular antioxidant. The maleimide moiety reacts with thiols to generate a luminescent $\mathrm{Tb}$ (III) complex, with a $\sim 5$-fold increase in emission intensity observed on reaction with a thiol. This was utilised to monitor the reduction of oxidised (disulfide) glutathione by glutathione reductase in the presence of $\mathrm{NADPH}$, leading to generation of reduced glutathione, with a free thiol group that reacts rapidly with the $\mathrm{Tb}$ (III) complex.

\section{Sensing of biological phosphoanions}

Biological phosphoanions represent an important class of molecules involved in a variety of cellular processes, including energy metabolism, DNA/RNA synthesis and organelle transport. ${ }^{149-151}$ Numerous enzyme reactions rely on the conversion between different phosphoanion species, for example, kinase reactions convert ATP to ADP, GTPases convert GTP to GDP. Therefore, the creation of probes capable of molecular recognition and sensing of these different species, could enable the development of enzyme assays for a range of enzyme classes.
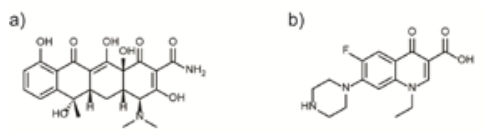

d)

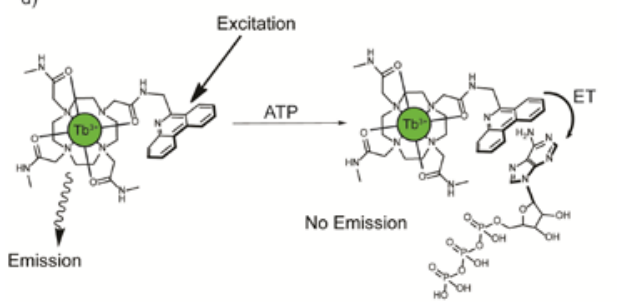

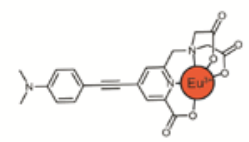

e)

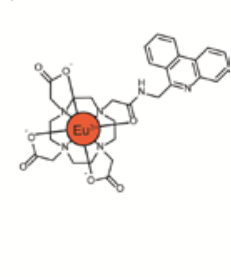

Figure 10. Lanthanide(III) complexes and ligands for sensing biological anions. a) Tetracycline, used as an Eu(III) ligand for sensing ATP and monitoring creatine kinase and alkaline phosphatase activity ${ }^{152}$ b) Norfloxacin, used as a $\mathrm{Tb}(\mathrm{III})$ ligand for monitoring adenylate cyclase and GTPase activity. ${ }^{153,154} \mathrm{c}$ ) Eu(III) complex which senses ATP and was used to monitor ATPase and apyrase activity. ${ }^{155} \mathrm{~d}$ ) Tb(III) probe capable of sensing (by $\pi$-stacking with the adenine base) and discriminating (by charge) ATP, ADP and AMP. ${ }^{156}$ e) Eu(III) complex used in combination with the $\mathrm{Tb}$ (III) complex in d) to develop a ratiometric PKA assay.

$\mathrm{Eu}(\mathrm{III})$ complexes of the antibiotic tetracycline (Figure 10a) and its derivatives have been developed as luminescent probes for ATP and phosphate, and utilised for real-time analysis of enzyme activity. ${ }^{152-155,157,158}$ The Schäfferling group showed that addition of ATP to a $1: 1$ mixture of Eu(III)/tetracycline caused significant (75\%) quenching of $\mathrm{Eu}(\mathrm{III})$ emission intensity. Using different ratios of $\mathrm{Eu}(\mathrm{III})$ ion to tetracycline, the activities of creatine kinase $(1: 1),{ }^{152}$ and alkaline phosphatase (3:1) were monitored, ${ }^{157}$ by measuring the increase in Eu(III) luminescence as a result of ATP hydrolysis. In subsequent work, a 1:1 mixture of $\mathrm{Tb}(\mathrm{III}) /$ norfloxacin (Figure 10b) was used to monitor the conversion of ATP to CAMP and pyrophosphate (PPi), catalysed by adenylate cyclase. ${ }^{153}$ A 5fold increase in emission intensity was observed on addition of ATP, whereas addition of PPi caused a 5 -fold decrease in emission and CAMP did not induce a spectral response. The probe was used to study the effect of the activator calmodulin, and to obtain inhibitor dose response curves. This compound was also used to monitor the activity of the GTPase Ras. ${ }^{154}$ In the absence of a guanine exchange factor (GEF), Ras has GTP or GDP bound, and does not release it, but gradually converts GTP to GDP with the release of phosphate. It was found that inorganic phosphate quenches the luminescence of a 1:1 mixture of $\mathrm{Tb}(\mathrm{III}) /$ norfloxacin by $90 \%$, therefore it could be used to monitor the increase in phosphate concentration as Ras hydrolyses GTP to GDP. ${ }^{154}$ Changes in enzyme reaction rate at different temperatures were monitored, as well as the action of GTPase activating proteins (GAPs). In recent work, the same researchers synthesised a pentadentate $\mathrm{Eu}(\mathrm{III})$ complex with an alkynylpyridine sensitiser (Figure 10c), which showed a large (60-fold) enhancement in luminescence upon binding to ATP. ${ }^{155}$ ADP induced a comparatively smaller 27-fold enhancement in emission intensity, whereas AMP showed a negligible spectral response. However, interference by the $\mathrm{Mg}^{2+}$ cofactor caused almost complete loss of sensing selectivity between ATP and ADP, due to competitive binding of $\mathrm{Mg}^{2+}$ to ATP. Nevertheless, it was possible to use the probe 
at low ionic strength to monitor the activity of ATPase (ATP to ADP) and apyrase (ATP or ADP to AMP) in real-time.

The Pierre group have developed $\operatorname{Ln}($ III) probes that can distinguish ATP and GTP from ADP and GDP respectively. ${ }^{156,159}$ Initially, a cyclen-based terbium(III) probe was synthesised with an phenanthridine antenna, capable of $\pi$-stacking with the adenine base of ATP, ADP and AMP (Figure 10d). This favourable interaction caused PeT quenching of the excited state of the phenanthridine antenna, resulting in a decrease in $\mathrm{Tb}$ (III) emission. ${ }^{159}$ Discrimination of the three species was achieved by differential electrostatic interactions between the positively charged $\mathrm{Tb}$ (III) complex and the phosphates of the nucleobases. They later used this complex, ${ }^{156}$ together with a similar but overall neutral Eu(III) complex (Figure 10e), to develop a ratiometric assay capable of detecting ATP/ADP and GTP/GDP ratios, by calibrating the changes in the $\mathrm{Tb}$ (III) emission bands against the less sensitive bands of the Eu(III) analogue. This was used to monitor the activity of protein kinase $A$, by measuring a decrease in the quenching of $\mathrm{Tb}$ (III) emission over the course of ATP to ADP conversion.

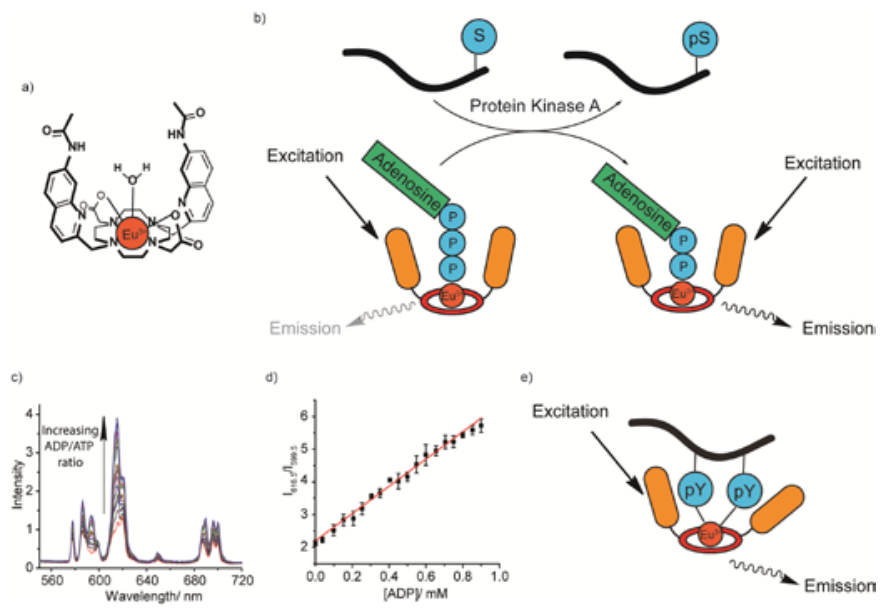

Figure 11. Monitoring of enzyme activity using an anion-responsive Eu(III) complex. ${ }^{160}$ a) Cationic Eu(III) complex used. b) Cartoon depicting sensing of the conversion of ATP to ADP during the PKA-catalysed phosphorylation of a serine containing peptide. Emission of the Eu(III) complex is enhanced upon conversion of ATP to ADP over the enzyme reaction. c) Variation in emission spectral form of the $E u(I I I)$ complex $(8 \mu \mathrm{M})$ on titration of ADP into ATP ( $1 \mathrm{mM}$ total concentration) in the presence of $3 \mathrm{mM} \mathrm{MgCl} 2 . \mathrm{d}$ ) The linear response observed in the emission intensity ratio, $616 / 599 \mathrm{~nm}$, on increasing ADP concentration. e) Cartoon showing sensing of adjacent phosphotyrosine residues using the same $\mathrm{Eu}(\mathrm{III})$ complex. ${ }^{161}$

Recently, we have prepared a cationic Eu(III) complex bearing two quinoline arms, ${ }^{162}$ for the discrimination of ATP and ADP (Figure 11). ${ }^{160}$ The Eu(III) complex binds reversibly to ATP and $A D P$, displacing the coordinated water molecule and producing distinctive changes in emission intensity and spectral form. Discrimination between ATP and ADP was enhanced in the presence of magnesium(II) ions, at concentrations used in conventional kinase assays, a factor which can often interfere with ATP/ADP discrimination. ${ }^{155}$ This enabled the change in the ratio of ATP/ADP to be monitored continuously during a PKA catalysed phosphorylation reaction, by measuring a ratiometric change in Eu(III) emission intensity (Figure 11c and d). The phosphorylation reaction was monitored at different enzyme concentrations, showing linearity between the concentration of enzyme and the initial rates of reaction. The $\mathrm{Eu}$ (III) probe was compatible with different biologically relevant conditions, including changes in $\mathrm{pH}$, addition of $\mathrm{NaCl}$, DTT and DMSO, and is well suited for screening of inhibitors (or activators) of kinase activity, as demonstrated by monitoring the effect of staurosporine on the activity of PKA. The ability to function in a wide range of conditions is particularly valuable in the design of general assays that can be used for classes of enzymes. In subsequent work, we demonstrated the ability of this Eu(III) complex to detect adjacent phosphotyrosine residues on pentapeptide sequences (Figure 11e), sensing the pYpY motif over YpY, YY, pSpS and PTpT motifs at similar concentrations. ${ }^{161}$ This enabled the acid phosphatase catalysed dephosphorylation of the peptide ApYpYAA to be monitored in real-time.

\section{Conclusions}

Monitoring enzyme reactions is of great importance for understanding enzyme mechanisms and inhibition. The advantages of using luminescent lanthanide complexes to probe enzyme activity have been demonstrated in a variety of ways. The unique photophysical properties of lanthanide ions provide advantages over conventional organic fluorophores, including large separations between the absorption and emission bands, line-like emission spectra, and long luminescence lifetimes, which permit time-resolved luminescence detection techniques. ${ }^{22}$ The existence of commercial assays, in the form of lanthanide-labelled antibodies, means that appropriate instrumentation already exists for the development of new lanthanide-based enzyme assays for use in high-throughput formats.

Reactivity-based probes have been devised to report on a variety of enzyme catalysed reactions, ${ }^{12}$ either by generating a lanthanide chelating antenna or modulating the photophysical properties of an attached antenna. Monitoring enzyme reactions in this manner does not allow for the use of native enzyme substrates and requires new lanthanide probes or ligand precursors to be synthesised for each enzyme of interest. However, with the design and synthesis of enzymespecific, cell permeable lanthanide probes it should be possible to monitor enzyme activity in real-time within cells. Indeed, some initial success in this regard has been achieved, detecting the activity at $\beta$-galactosidase in lac $Z$ bacteria. ${ }^{63}$ This is a potentially powerful tool that several alternative types of enzyme assays would not be capable of performing, and is certainly a field to be pursued further.

Lanthanide labelled biomolecules (e.g. antibodies) have shown great utility as end-point assays for enzyme reactions in vitro, with several commercial assays already existing based on these techniques. The recognition of the enzymatic products by lanthanide labelled antibodies allows for the progress of the enzyme reaction to be determined. The development of these assays into commercial products shows the reliability and practicability of this approach, and has lead to the 
development of lanthanide-applicable instrumentation for high-throughput screening, a factor that will facilitate further advances in this area. The development of new antibodies, and Ln(III) labelled derivatives, for an increasing number of enzymatic products will allow for increasingly specific enzyme assays to be developed.

The labelling of other proteins and peptides can allow monitoring of enzyme reactions in real-time, and permits the use of low concentrations of reagents. The labelling of peptides with conventional organic fluorophores is common to many biological assays, 7,113,115,163 including for ligand binding, and this is being extended readily to exploit the many advantages of luminescent lanthanide complexes. ${ }^{14,15,109,118}$ Care must be taken in selecting the location and size of the attached label, to ensure minimal perturbation of the enzyme reaction or inhibitor binding. However, given the widespread use of fluorescently labelled peptides and proteins, this is unlikely to be seen as a major stumbling block to the adoption of this technology.

The use of discrete lanthanide complexes to monitor enzyme reactions is a progressing field, which have already shown potential for detecting peptide modifications (e.g. phosphorylation/dephosphorylation), ${ }^{136,161}$ and monitoring the formation/depletion of biological anions. ${ }^{160}$ Importantly, the use of discrete lanthanide probes enables the use of native enzymes and substrates, and allows the reaction to be monitored in real-time. This approach offers the potential to develop highly versatile assays that can be applied to whole classes of enzymes, by sensing common post-translational modifications or the conversion between common biological anions or molecules. For example, a probe that can accurately signal the phosphorylation of an amino acid, or the conversion of ATP to ADP, enables a general assay for kinases to be developed, which is not limited to a particular peptide/protein substrate or enzyme. While the development of such assays is in its infancy, opportunities are available to create robust, accurate and high-throughput assays that allow the screening of enzyme activity, selectivity and inhibitors. Further advances in lanthanide-based enzyme assay development are expected in the near future, which may provide attractive alternatives to existing commercial assay formats, thus facilitating drug discovery.

\section{Conflicts of interest}

There are no conflicts to declare.

\section{Acknowledgments}

S.J.B and S.H.H would like to thank the Wellcome Trust for support (204500/Z/16/Z).

\section{Notes and references}

1 R. A. Copeland, Evaluation of enzyme inhibitors in drug discovery: a guide for medicinal chemists and pharmacologists, 2013.

W. P. Janzen, Chem. Biol., 2014, 21, 1162-1170.

M. G. Acker and D. S. Auld, Perspect. Sci., 2014, 1, 56-73.

Y. Wang and H. Ma, Drug Discov. Today Technol., 2015, 18, 1-8.

5 P. Gribbon and A. Sewing, Drug Discov. Today, 2003, 8, 1035-1043.

S. M. Borisov and O. S. Wolfbeis, Chem. Rev., 2008, 108, 423-461.

7 D. S. Lawrence and Q. Wang, ChemBioChem, 2007, 8, 373378.

8 H. M. Burke, T. Gunnlaugsson and E. M. Scanlan, Chem. Commun., 2015, 51, 10576-10588.

G. Casey and C. Stains, Chem. - A Eur. J., 2018, 24, 1-16. G. K. Wagner and T. Pesnot, ChemBioChem, 2010, 11, 1939-1949.

11 S. V Eliseeva and J.-C. G. Bünzli, Chem. Soc. Rev., 2010, 39, 189-227.

E. Pershagen and K. E. Borbas, Coord. Chem. Rev., 2014, 273-274, 30-46.

R. Evangelista, A. Pollak and E. Templeton, Anal. Biochem., 1991, 197, 213-224.

L. Ancel, A. Niedźwiecka, C. Lebrun, C. Gateau and P. Delangle, Comptes Rendus Chim., 2013, 16, 515-523. K. N. Allen and B. Imperiali, Curr. Opin. Chem. Biol., 2010, 14, 247-254.

16 P. R. Selvin, Annu. Rev. Biophys. Biomol. Struct., 2002, 31, 275-302.

E. Pazos and M. E. Vázquez, Biotechnol. J., 2014, 9, 241252.

M. Sy, A. Nonat, N. Hildebrandt and L. J. Charbonnière, Chem. Commun., 2016, 52, 5080-5095.

C. M. Spangler, C. Spangler and M. Schäerling, Ann. N. Y. Acad. Sci., 2008, 1130, 138-148.

M. C. Heffern, L. M. Matosziuk and T. J. Meade, Chem. Rev., 2014, 114, 4496-4539.

J. Vuojola and T. Soukka, Methods Appl. Fluoresc., 2014, 2, 12001.

J. C. G. Bünzli, J. Lumin., 2016, 170, 866-878.

D. Parker, Chem. Soc. Rev., 2004, 33, 156.

S. Faulkner, S. J. A. Pope and B. P. Burton-Pye, Appl. Spectrosc. Rev., 2005, 40, 1-31.

J. Yuan and G. Wang, TrAC - Trends Anal. Chem., 2006, 25, 490-500.

Y. Jia, C. M. Quinn, A. I. Gagnon and R. Talanian, Anal. Biochem., 2006, 356, 273-281.

A. K. Hagan and T. Zuchner, Anal. Bioanal. Chem., 2011, 400, 2847-2864. S. J. Butler, L. Lamarque, R. Pal and D. Parker, Chem. Sci. 2014, 5, 1750.

S. M. Riddle, K. L. Vedvik, G. T. Hanson and K. W. Vogel, Anal. Biochem., 2006, 356, 108-116. D. Geißler and N. Hildebrandt, Curr. Inorg. Chem., 2011, 1, 17-35.

31 J. M. Zwier, H. Bazin, L. Lamarque and G. Mathis, Inorg. Chem., 2014, 53, 1854-1866.

32 E. M. Surender, S. Comby, B. L. Cavanagh, O. Brennan, T. C. 
Lee and T. Gunnlaugsson, Chem, 2016, 1, 438-455. A. J. Palmer, S. H. Ford, S. J. Butler, T. J. Hawkins, P. J. Hussey, R. Pal, J. W. Walton and D. Parker, RSC Adv., 2014, 4, 9356.

E. G. Moore, A. P. S. Samuel and K. N. Raymond, Acc. Chem. Res., 2009, 42, 542-552. J. C. G. Bünzli, Coord. Chem. Rev., 2015, 293-294, 19-47. S. Shuvaev, M. Starck and D. Parker, Chem. - A Eur. J., 2017, 9974-9989.

S. J. Butler, M. Delbianco, L. Lamarque, B. K. McMahon, E.

R. Neil, R. Pal, D. Parker, J. W. Walton and J. M. Zwier, Dalt. Trans., 2015, 44, 4791-4803. S. J. Butler and D. Parker, Chem. Soc. Rev., 2013, 42, 16521666.

A. K. R. Junker, M. Tropiano, S. Faulkner and T. J. Sørensen, Inorg. Chem., 2016, 55, 12299-12308.

A. T. Bui, A. Grichine, A. Duperray, P. Lidon, F. Riobé, C. Andraud and O. Maury, J. Am. Chem. Soc., 2017, 139, 7693-7696.

E. G. Moore, J. Xu, C. J. Jocher, T. M. Corneillie and K. N. Raymond, Inorg. Chem., 2010, 49, 9928-9939.

S. Petoud, S. M. Cohen, J. C. G. Bünzli and K. N. Raymond, J. Am. Chem. Soc., 2003, 125, 13324-13325.

S. Petoud, G. Muller, E. G. Moore, J. Xu, J. Sokolnicki, J. P. Riehl, U. N. Le, S. M. Cohen and K. N. Raymond, J. Am. Chem. Soc., 2007, 129, 77-83.

K. Barthelmes, A. M. Reynolds, E. Peisach, H. R. A. Jonker, N. J. Denunzio, K. N. Allen, B. Imperiali and H. Schwalbe, J. Am. Chem. Soc., 2011, 133, 808-819.

A. Beeby, I. M. Clarkson, R. S. Dickins, S. Faulkner, D. Parker, L. Royle, A. S. de Sousa, J. A. G. Williams and M. Woods, J. Chem. Soc. Perkin Trans. 2, 1999, 2, 493-504. G. R. Choppin and D. R. Peterman, Coord. Chem. Rev., 1998, 174, 283-299.

D. F. Caffrey and T. Gunnlaugsson, Dalt. Trans., 2014, 43, 17964-17970.

R. Pal, D. Parker and L. C. Costello, Org. Biomol. Chem., 2009, 7, 1525.

M. S. Tremblay, M. Halim and D. Sames, J. Am. Chem. Soc., 2007, 129, 7570-7577.

M. Tropiano and S. Faulkner, Chem. Commun., 2014, 50, 4696-4698.

E. P. Diamandis, Analyst, 1992, 117, 1879-1884.

C. J. Veiopoulou, E. S. Lianidou, P. C. Ioannou and C. E. Efstathiou, Anal. Chim. Acta, 1996, 335, 177-184. J. Meyer and U. Karst, Analyst, 2000, 125, 1537-1538. T. Steinkamp and U. Karst, Anal. Chim. Acta, 2004, 526, 2734.

T. Steinkamp, F. Schweppe, B. Krebs and U. Karst, Analyst, 2003, 128, 29-31.

C. Q. Jiang and N. Zhang, J. Pharm. Biomed. Anal., 2004, 35, 1301-1306.

N. Zhang, J.-K. Liu and C.-Q. Jiang, Anal. Sci., 2005, 21, 541544.

S. Bhowmik and U. Maitra, Chem. Commun., 2012, 48, 4624.
E. F. Gudgin Dickson, A. Pollak and E. P. Diamandis, J. Photochem. Photobiol. B Biol., 1995, 27, 3-19.

T. Terai, K. Kikuchi, Y. Urano, H. Kojima and T. Nagano, Chem. Commun., 2012, 48, 2234.

T. Terai, K. Kikuchi, S. Y. Iwasawa, T. Kawabe, Y. Hirata, Y. Urano and T. Nagano, J. Am. Chem. Soc., 2006, 128, 69386946.

E. Pershagen, J. Nordholm and K. E. Borbas, J. Am. Chem. Soc., 2012, 134, 9832-9835.

E. Pershagen and K. E. Borbas, Angew. Chemie - Int. Ed., 2015, 54, 1787-1790.

T. Terai, H. Ito, K. Kikuchi and T. Nagano, Chem. - A Eur. J., 2012, 18, 7377-7381.

S. Mizukami, K. Tonai, M. Kaneko and K. Kikuchi, J. Am. Chem. Soc., 2008, 130, 14376-14377.

H. M. Burke, T. Gunnlaugsson and E. M. Scanlan, Org. Biomol. Chem., 2016, 14, 9133-9145.

L. E. Morrison, Anal. Biochem., 1988, 174, 101-120. I. Hemmilá and V. M. Mukkala, Crit. Rev. Clin. Lab. Sci., 2001, 38, 441-519. . Hemmilä, S. Dakubu, V. M. Mukkala, H. Siitari and T. Lövgren, Anal. Biochem., 1984, 137, 335-343.

E. Soini and H. Kojola, Clin. Chem., 1983, 29, 65-68.

F. Degorce, Curr. Chem. Genomics, 2009, 3, 22-32. Y.-W. Park, R. ichard T. Cummings, L. Wu, S. Zheng, P. M. Cameron, A. Woods, D. M. Zaller, A. I. Marcy and J. D. Hermes, Anal. Biochem., 1999, 269, 94-104. . Bazin, E. Trinquet and G. Mathis, Rev. Mol. Biotechnol. 2002, 82, 233-250.

B. Alpha-Bazin and E. Quemeneur, Anal. Chem., 2012, 84, 9963-9970.

G. Gabant, A. Lorphelin, N. Nozerand, C. Marchetti, L. Bellanger, A. Dedieu, E. Quéméneur and B. Alpha-Bazin, J. Mol. Biol., 2008, 380, 489-503.

M. A. S. Hass and M. Ubbink, Curr. Opin. Struct. Biol., 2014, 24, 45-53.

P. H. J. Keizers and M. Ubbink, Prog. Nucl. Magn. Reson. Spectrosc., 2011, 58, 88-96.

C. Nitsche and G. Otting, Prog. Nucl. Magn. Reson. Spectrosc., 2017, 98-99, 20-49.

S. Engilberge, F. Riobé, S. Di Pietro, L. Lassalle, N. Coquelle, C.-A. Arnaud, D. Pitrat, J.-C. Mulatier, D. Madern, C. Breyton, O. Maury and E. Girard, Chem. Sci., 2017, 8, 59095917.

H. G. Brittain, F. S. Richardson and R. B. Martin, J. Am. Chem. Soc., 1976, 98, 8255-8260.

J. De Jersey and R. B. Martin, Biochemistry, 1980, 19, 11271132.

J. De Jersey, R. S. Lahue and R. B. Martin, Arch. Biochem. Biophys., 1980, 205, 536-542. 1999, 274, 4082-4088.

Y. Koshi, E. Nakata and I. Hamachi, ChemBioChem, 2005, 6, 1349-1352.

86 A. M. Reynolds, B. R. Sculimbrene and B. Imperiali, Bioconjug. Chem., 2008, 19, 588-591. 
QSAR Comb. Sci., 2005, 24, 1149-1157.

88 L. J. Martin, M. J. Hähnke, M. Nitz, J. Wöhnert, N. R. Silvaggi, K. N. Allen, H. Schwalbe and B. Imperiali, J. Am. Chem. Soc., 2007, 129, 7106-7113.

89 M. Nitz, M. Sherawat, K. J. Franz, E. Peisach, K. N. Allen and B. Imperiali, Angew. Chemie - Int. Ed., 2004, 43, 36823685. K. J. Franz, M. Nitz and B. Imperiali, ChemBioChem, 2003, 4, 265-271.

91 B. R. Sculimbrene and B. Imperiali, J. Am. Chem. Soc., 2006, 128, 7346.

92 J. Vuojola, M. Syrjänpää, U. Lamminmaki and T. Soukka, Anal. Chem., 2013, 85, 1367-1373.

93 M. Nitz, K. J. Franz, R. L. Maglathlin and B. Imperiali, ChemBioChem, 2003, 4, 272-276.

94 C. W. Am Ende, H. Y. Meng, M. Ye, A. K. Pandey and N. J. Zondlo, ChemBioChem, 2010, 11, 1738-1747.

95 T. Hunter, Cell, 2000, 100, 113-127.

96 G. Manning, Science (80-. )., 2002, 298, 1912-1934.

97 L. L. Liu and K. J. Franz, J. Am. Chem. Soc., 2005, 127, 9662 9663.

98 L. L. Liu and K. J. Franz, J. Biol. Inorg. Chem., 2007, 12, 234247.

99 S. Balakrishnan and N. J. Zondlo, J. Am. Chem. Soc., 2006, 128, 5590-5591.

100 S. C. Zondlo, F. Gao and N. J. Zondlo, J. Am. Chem. Soc., 2010, 132, 5619-5621.

101 A. M. Lipchik and L. L. Parker, Anal. Chem., 2013, 85, 25822588.

102 A. M. Lipchik, M. Perez, W. Cui and L. L. Parker, Anal. Chem., 2015, 87, 7555-7558.

103 W. Cui and L. L. Parker, Chem. Commun., 2015, 51, 362365.

104 W. Cui and L. L. Parker, Nat. Publ. Gr., 2016, 1-8.

105 A. M. Lipchik, M. Perez, S. Bolton, V. Dumrongprechachan, S. B. Ouellette, W. Cui and L. L. Parker, J. Am. Chem. Soc., 2015, 137, 2484-2494.

106 A. M. Lipchik, R. L. Killins, R. L. Geahlen and L. L. Parker, Biochemistry, 2012, 51, 7515-7524.

107 P. K. L. Fu and C. Turro, J. Am. Chem. Soc., 1999, 121, 1-7.

108 S. L. Klakamp and W. D. Horrocks, J. Inorg. Biochem., 1992, 46, 175-192.

109 J. Peuralahti, H. Hakala, V. M. Mukkala, K. Loman, P. Hurskainen, O. Mulari and J. Hovinen, Bioconjug. Chem., 2002, 13, 870-875.

110 P. Sista, K. Ghosh, J. S. Martinez and R. C. Rocha, Polym. Rev., 2014, 54, 627-676.

111 K. L. Gempf, S. J. Butler, A. M. Funk and D. Parker, Chem. Commun., 2013, 49, 9104.

112 N. Kawasaki and Y. C. Lee, Anal. Biochem., 1997, 250, 260262.

113 E. Pazos, O. Vázquez, J. L. Mascareñas and M. Eugenio Vázquez, Chem. Soc. Rev., 2009, 38, 3348.

114 V. Sharma, Q. Wang and D. S. Lawrence, Biochim. Biophys. Acta - Proteins Proteomics, 2008, 1784, 94-99.

115 J. A. González-Vera, Chem. Soc. Rev., 2012, 41, 1652-1664.

116 M. S. Tremblay, Q. Zhu, A. A. Mart, J. Dyer, S. Jockusch, N.

J. Turro, D. Sames, A. A. Martı and M. Halim, Org. Lett., 2006, 8, 2723-2726.

117 
140 A. B. Aletti, D. M. Gillen and T. Gunnlaugsson, Coord. Chem. Rev., 2017, 1-23.

141 T. Liu, A. Nonat, M. Beyler, M. Regueiro-Figueroa, K. Nchiminono, O. Jeannin, F. Camerel, F. Debaene, S. Cianférani-Sanglier, R. Tripier, C. Platas-Iglesias and L. J. Charbonnière, Angew. Chemie - Int. Ed., 2014, 53, 72597263.

142 M. L. Aulsebrook, B. Graham, M. R. Grace and K. L. Tuck, Coord. Chem. Rev., , DOI:10.1016/j.ccr.2017.11.018.

143 M. L. Aulsebrook, S. Biswas, F. M. Leaver, M. R. Grace, B. Graham, A. M. Barrios and K. L. Tuck, Chem. Commun., 2017, 53, 4911-4914.

144 H. Ito, T. Terai, K. Hanaoka, T. Ueno, T. Komatsu, T. Nagano and Y. Urano, Chem. Commun., 2015, 51, 8319-22.

145 T. Terai, H. Ito, K. Hanaoka, T. Komatsu, T. Ueno, T. Nagano and Y. Urano, Bioorganic Med. Chem. Lett., 2016, 26, 2314-2317.

146 R. A. Poole, F. Kielar, S. L. Richardson, P. A. Stenson and D. Parker, Chem. Commun., 2006, 4084.

147 E. M. Surender, S. J. Bradberry, S. A. Bright, C. P. McCoy, D. Clive Williams and T. Gunnlaugsson, J. Am. Chem. Soc., 2017, 139, 381-388.

148 B. K. McMahon and T. Gunnlaugsson, J. Am. Chem. Soc., 2012, 134, 10725-10728.

149 C. T. Walsh, B. P. Tu and Y. Tang, Chem. Rev., 2017, acs.chemrev.7b00510.

150 T. Sakamoto, A. Ojida and I. Hamachi, Chem. Commun., 2009, 141-52.

151 A. E. Hargrove, S. Nieto, T. Zhang, J. L. Sessler and E. V. Anslyn, Chem. Rev., 2011, 111, 6603-6782.

152 M. Schäferling and O. S. Wolfbeis, Chem. - A Eur. J., 2007, 13, 4342-4349.

153 C. M. Spangler, C. Spangler, M. Göttle, Y. Shen, W. J. Tang, R. Seifert and M. Schäferling, Anal. Biochem., 2008, 381, 86-93.

154 C. Spangler, C. M. Spangler, M. Spoerner and M. Schäferling, Anal. Bioanal. Chem., 2009, 394, 989-996.

155 M. Schäferling, T. Ääritalo and T. Soukka, Chem. - A Eur. J., 2014, 20, 5298-5308.

156 E. A. Weitz, J. Y. Chang, A. H. Rosenfield, E. A. Morrow and V. C. Pierre, Chem. Sci., 2013, 4, 4052.

157 P. Schrenkhammer, I. C. Rosnizeck, A. Duerkop, O. S. Wolfbeis and M. Schäferling, J Biomol Screen, 2008, 13, 916.

158 S. Nagl, N, M. I. J. Stich, M. Schäferling and O. S. Wolfbeis, Anal. Bioanal. Chem., 2009, 393, 1199-1207.

159 E. A. Weitz, J. Y. Chang, A. H. Rosenfield and V. C. Pierre, J. Am. Chem. Soc., 2012, 134, 16099-16102.

160 S. H. Hewitt, J. Parris, R. Mailhot and S. J. Butler, Chem. Commun., 2017, 53, 12626-12629.

161 S. H. Hewitt, R. Liu and S. J. Butler, Supramol. Chem., 2017, 278, 1-7.

162 S. J. Butler, Chem. Commun., 2015, 51, 10879-10882.

163 A. T. Krueger and B. Imperiali, ChemBioChem, 2013, 14, 788-799. 